Rogério Baptistini MENDES

\title{
Palavra e poder: os intelectuais na sociedade brasileira
}

Entre 23 e 25 de fevereiro de 1989, a Universidade Católica da Eichstätt sediou um simpósio onde se discutiu o papel desempenhado pelos intelectuais brasileiros no periodo correspondente à ditadura militar, instaurada em 1964, e à redemocratização política que se seguiu. Na ocasião, marcaram presença personalidades como o embaixador brasileiro na extinta República Democrática Alemã.

Oscar S. Lorenzo-Fernandez e o escritor Luís Veríssimo, com suas conferências, ajudaram a analisar o comportamento de uma geração que enfrentou o exercício arbitrário do poder, manipulando sutil e corajosamente a palavra. Ainda que o resultado final do evento, atestado no livro Palavra e poder: os intelectuais na sociedade brasileira, tenha deixado muitas perguntas sem respostas, o que é natural em situações como essa, ele contribui para que possamos apreender o clima do período e verificar sua influência na produção intelectual de uma geração que buscava soluções para as demandas urgentes de seu tempo e ainda tinha de preocupar-se com a perseguição, tortura e exílio com que os militares presenteavam seus desafetos.

Em se tratando de tema imediatamente relacionado ao intelectual brasileiro, não poderia faltar a referência histórica da qual ele é tributário e que, por paradoxal que possa parecer, nos anos da ditadura marcaram-no de forma irremediável. Assim, é na gestação dessa categoria que vamos encontrar subsídios para compreender a sua atuação política, seja como adesista do regime, seja como oposicionista, pois é necessário lembrarmos que, ao intelectual brasileiro, não é estranha a sensação de constituir-se num sujeito dotado de uma vocação especial, unificadora e educadora da Nação. Neste sentido, a discussão proposta por Edgar Salvadore De Decca durante sua conferência no referido simpósio é significativa, embora restem dúvidas quanto à recente incapacidade dos intelectuais de moldar um projeto para toda a sociedade. 
A tese defendida por Edgar De Decca é a de que o processo de edemocratização política marcou a fragmentação dos objetivos dos intelectuais, que passaram a atuar conjuntamente com os demais atores políticos na busca da cidadania. Em última instância, isso corresponde a afirmar qua já não há relação necessária entre a condição de intelectual e a de ator político. $O$ intelectual brasileiro, que se julgava portador da identidade nacional, e por isso na mesma situação do político, devendo moldar a sociedade, transformou-se no intérprete das massas e, agora, com a chegada da democracia e o surgimento de toda uma complexidade social que permanecia abafada, não é mais do que um indivíduo como qualquer outro, que se organiza em função dos seus interesses corporativos e participa como cidadão nos organismos de representação política.

Essa discussão sobre a condição dos intelectuais reloca a questão das relações entre Estado e sociedade no centro da análise, pois dela derivam os acordos e os desacordos quanto ao sentido de missão desta categoria, que diante da debilidade da sociedade busca uma saída para o seu constrangimento na presunção de transformar as estruturas sociais pelo poder das idéias. O Estado a serviço do bem comum é o mote de uma geração; depois, é contra a arbitrariedade deste mesmo Estado que outra geração se insurge, sem no entanto confirmar a tese da ausência do sentido de missão. Ao surgimento de demandas originadas numa sociedade civil complexa, que veio a consolidar-se num contexto em que o Estado impulsiona a modernização do País, a intelectualidade responde colocando em pauta o tema do "mais Estado e menos Estado", sendo delatora de suas perversidades e reclamante de sua ação para a solução dos mais diversos problemas.

Hartmut Sangmeister, cujo ensaio "Os intelectuais e o Estado no processo de redemocratização política: uma relação ambígua" foi apresentado no simpósio que discutimos, crê que este dilema sobre o tamanho do Estado se origina na contradição vivida pelos intelectuais em face da democratização política. Para o autor, denunciando a responsabilidade do Estado em relação aos problemas do País e reclamando a sua intervenção para a resolução de outros tantos problemas sociais, a intelectualidade cumpre uma "dupla e ambiciosa tarefa", conseqüência de "uma antinomia democrática, característica comum de pós-modernidade e de um novo conceito de liberdade, mais subjetiva, mais espontânea, mais direta".

Há ainda outra discussão subjacente ao simpósio sobre os intelectuais brasileiros realizado na Alemanha, que está presente na seguinte pergunta, elaborada por Karl Kohut, responsável pela edição do livro: quais os princípios morais que determinam as relações dos intelectuais com o poder? Antes de formulá-la, porém, ele procura definir o conceito teórico de intelectual, refletindo sobre a crise que 0 atingiu $e$ precedeu a crise do marxismo. As definições clássicas acerca do substantivo servem para que se conclua que os intelectuais, para uns, estão ligados à revolução e, para outros, ao poder. Assim, as definições de Gramsci, Mannheim, Ortega y Gasset, Sartre e Julien Benda são contrastadas para permitir a formulação de uma idéia sobre a 
função e o ser do intelectual, o que permitirá o estudo de sua atuação na história recente do Brasil, finalidade do evento ocorrido há três anos.

A pergunta sobre os princípios morais que regem as relações intelectuais apóia-se na constatação de que, apesar de o intelectual caracterizar-se pela reflexão e o político pela ação, ambos encontram-se no mesmo espaço, que é designado como sendo a opinião pública. Ali, e somente ali, o intelectual se realiza como tal, onde os "eternos e substanciais princípios da justiça" são abarcados na forma do senso comum. Neste sentido, ganha dimensão importante a intelectualidade quando a opinião pública não encontra meios de exprimir-se livremente, por encontrar-se sob censura. $O$ poder de dissimulação da crítica à realidade presente nas obras intelectuais, sobretudo na literatura, realça o papel desta categoria, principalmente no caso latino-americano.

Num contexto onde, ao lado da censura aos meios de expressão da opinião pública, dominava a confusão de valores que deveriam nortear a conduta social, com atentados em nome de uma moral cristã, a atuação dos intelectuais ganha um relevo especial, pois thes cabe promover a separação entre os valores falsos e autênticos, denunciando o exercício arbitrário do poder e os obstáculos que se colocam à realização das liberdades individuais. Como pretende Karl Kohut, a palavra deve se insurgir contra o poder em defesa dos direitos humanos, e isso uma geração de intelectuais brasileiros não deixou de fazer, tendo produzido uma literatura que não abandonou a disposição de retratar a verdadeira face do "País dos milagres econômicos".

O livro Palavra e poder: os intelectuais na sociedade brasileira, que reúne o conjunto de conferências acerca do intelectual brasileiro, contém ainda análises e informações sobre as instituições sociais e as relações entre jornalismo e literatura durante o período em questão. Merecem destaque, além dos já citados, os textos de autoria de Maria Christina S. de Souza Campos e de Antonio Hohfeldt, intitulados "As universidades brasileiras como centros de resistência" e "Relações entre jornalismo e literatura na década de 70", respectivamente. Completam a obra, contribuições de Joaquim Pedro de Souza Campos, Christiano German, Achim Schrader, Angela Pacheco Pimenta e Moacyr Scliar. 